Check for updates

The BMJ

rhurley@bmj.com Follow Richard on Twitter@rich_hurley Cite this as: BMJ 2020;370:m2730 http://dx.doi.org/10.1136/bmj.m2730 Published: 09 July 2020

\section{Moving quickly in pandemics}

\author{
Richard Hurley features and debates editor
}

Speed is of the essence in responding to the covid-19 pandemic. But in Leicester lockdown has been reimposed because information was shared too slowly. Local authorities lacked centrally held data to detect a rise in cases and act swiftly. In an editorial this week Mike Gill, Devi Sridhar, and Fiona Godlee describe a "chaotic system" in England that seems to focus on increasing test numbers instead of establishing a local testing strategy designed to contain the virus and save lives. ${ }^{1}$ They blame the government's "paternalistic, centralising tendency" and lack of trust in local professionals.

Wales shares covid-19 data locally. Scotland's “zero covid” test, trace, and isolate strategy is built on existing local capacity and locally led tracing, with daily public reports on testing. ${ }^{2}$ This open, strategic approach, including clear lines of accountability, is working, the editorialists argue. England will see further lockdowns and deaths "without swift and decisive action by those at local and national levels who understand communicable disease control," they say. ${ }^{1}$

Information from trials can enable speedy decisions. The rapidly convened RECOVERY trial is currently assessing dexamethasone in children, azithromycin, tocilizumab, and plasma. ${ }^{3}$ This "platform trial” involves over 175 UK hospitals, 3500 healthcare professionals, and 15\% of all hospital patients with covid-19.

On 16 June a government press conference announced that the RECOVERY trial had shown that dexamethasone had lowered mortality by up to a third among patients with hypoxaemia. The NHS treatment protocol immediately changed to include dexamethasone. It was another week before the researchers published a preprint.

Our editorialists Raymond Johnson and Joseph Vinetz argue against delaying use of a widely available treatment that has shown to reduce deaths. ${ }^{4}$ But they caution against communicating clinical trial data early through press releases. "Clinicians and policy makers need access to detailed data and analyses before making or accepting therapeutic decisions or recommendations.” They also acknowledge many unanswered questions: which corticosteroid works best, and the timing, dose, and duration of treatment. The benefits and risks of dexamethasone for the oldest adults remain unclear, they point out.

Martin Landray, deputy chief investigator of the RECOVERY trial, tells The BMJ, "If we hadn't released the [results], people would have said we sat on it." ${ }^{3}$ We needed to find treatments quickly to reduce deaths, Landray says, commenting on the trial's simple design: "It had to be easy for the clinician on the ground, in PPE and in a pressurised situation, and a minimal burden for the patient."

The trial has critics too, but Landray is unfazed. He wants to apply lessons from RECOVERY's scale and speed to key challenges such as heart disease, cancer, arthritis, and mental health. The aim should also be, as with covid-19 testing in Leicester, to ensure that the data and methods are available and open to scrutiny.

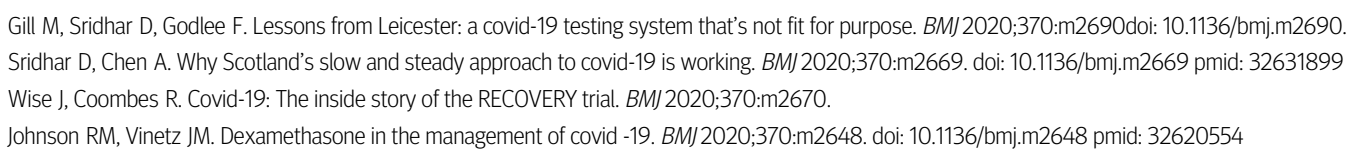

Gill M, Sridhar D, Godlee F. Lessons from Leicester: a covid-19 testing system that's not fit for purpose. BMJ 2020;370:m2690doi: 10.1136/bmj.m2690 Sridhar D, Chen A. Why Scotland's slow and steady approach to covid-19 is working. BMJ2020;370:m2669. doi: 10.1136/bmj.m2669 pmid: 32631899 Wise J, Coombes R. Covid-19: The inside story of the RECOVERY trial. BMJ2020;370:m2670.

Johnson RM, Vinetz JM. Dexamethasone in the management of covid -19. BMJ2020;370:m2648. doi: 10.1136/bmj.m2648 pmid: 32620554

This article is made freely available for use in accordance with BMJ's website terms and conditions for the duration of the covid-19 pandemic or until otherwise determined by BMJ. You may use, download and print the article for any lawful, non-commercial purpose (including text and data mining) provided that all copyright notices and trade marks are retained. 